\title{
PERBANDINGAN PENDEKATAN REFORMASI METROPOLITAN DALAM MENYELESAIKAN ISU KOMUTER DI JAKARTA METROPOLITAN AREA
}

\author{
Erie Sadewo ${ }^{1}$, Ibnu Syabri ${ }^{2}$ \\ ${ }^{1}$ Sekolah Arsitektur, Perencanaan, dan Pengembangan Kebijakan, ITB, Indonesia \\ ${ }^{2}$ Badan Pusat Statistik \\ ${ }^{1}$ Email: erie@s.itb.ac.id
}

Diterima (received): 21 Januari 2018

Disetujui (accepted): 17 Maret 2018

\begin{abstract}
ABSTRAK
Isu komuter merupakan persoalan metropolitan yang terjadi secara lintas batas wilayah. Persoalan dalam komuter berkembang akibat terjadinya fragmentasi pembangunan yang menyebabkan ketidakseimabngan lokasi bekerja dan tempat tinggal. Dalam era desentralisasi di Indonesia, upaya untuk mengatasi persoalan komuter menjadi semakin sulit karena ketiadaan institusi yang mampu melakukan tata kelola komuter pada skala metropolitan. Pada tulisan ini disajikan perbandingan pendekatan reformasi metropolitan yang dapat dipergunakan untuk menyelesaikan permasalahan komuter di Jakarta Metropolitan Area (JMA). Hasilnya didapati bahwa rescaling institusi pemerintah pusat dengan pelibatan unsur pemerintah lokal didalamnya dinilai sebagai pendekatan yang paling tepat untuk mengatasi persoalan tersebut.
\end{abstract}

Kata Kunci: komuter, desentralisasi, tata kelola

\section{A. PENDAHULUAN}

Perencanaan pembangunan perkotaan di masa depan akan menghadapi tantangan yang semakin berat. Pada tahun 2050 diperkirakan bahwa 66 persen penduduk dunia akan bertempat tinggal di perkotaan (United Nations, Department of Economic and Social Affairs, \& Population Division, 2014). Tingginya jumlah penduduk di perkotaan tersebut akan menimbulkan berbagai permasalahan terkait dengan ketersediaan lahan dan energi yang dapat mengancam keberlanjutan pembangunan. Untuk mengantisipasi permasalahan tersebut, salah satu solusi yang ditawarkan berupa dukungan terhadap implementasi kebijakan pembangunan teritorial yang berimbang dan polisentris, yang mengedepankan kerjasama dan saling mendukung antara berbagai skala kota serta permukiman yang berbeda ("HABITAT III: New Urban Agenda," 2016).

Kesuksesan desentralisasi pembangunan perkotaan terletak pada dua hal yaitu lokasi permukiman serta aktivitas ekonomi (Camagni, Gibelli, \& Rigamonti, 2002). Dalam hal ini, struktur perkotaan yang polisentris dianggap mampu menghadirkan hipotesis ko-lokasi, yaitu orang cenderung untuk bekerja pada lokasi yang berdekatan dengan tempat tinggalnya, melalui pusat kota yang kompak dan terhubung dengan baik pada pusat kota lainnya melalui jaringan transportasi publik. Hal ini akan mendorong mobilitas penduduk, terutama untuk kegiatan bekerja, untuk berlangsung lebih singkat dan efisien. Namun berbagai fakta empiris justru memperlihatkan hasil yang sebaliknya . 
Struktur spasial merupakan kombinasi antara morfologi dan fungsi aktivitas faktor kunci dalam menjelaskan bangkitan perjalanan (Giuliano \& Small, 1993). Penelitian terhadap perbandingan hubungan antara pola komuter pekerja dengan berbagai karakteristik metropolitan pada tingkat individu, rumah tangga, lingkungan, dan metropolitan menunjukkan bahwa struktur polisentris tidak menghasilkan jarak dan waktu komuter yang lebih singkat bagi pengguna mobil (Schwanen, Dieleman, \& Dijst, 2004). Sementara itu, hasil penelitian tentang hipotesis ko-lokasi dan hubungannya dengan pola komuter menyimpulkan bahwa jarak yang harus ditempuh akibat berkembangnya jumlah pekerjaan pada suatu sub-pusat pada metropolitan polisentris justru semakin menjauh (Aguilera, 2005). Hal ini kemudian menimbulkan pertanyaan mengenai seberapa besar pengaruh perubahan struktur spasial perkotaan terhadap pola mobilitas?.

Dalam konteks Indonesia, pertanyaan tersebut menjadi penting untuk dijawab, mengingat pembangunan perkotaan Indonesia memiliki karakteristik yang berbeda dibandingkan dengan negara lain. Laporan Bank Dunia Tahun 2016 menunjukkan bahwa kota-kota di Indonesia memiliki karakteristik populasi dan luas yang tumbuh dengan cepat, namun telah kehilangan kesempatan yang dihasilkan oleh urbanisasi akibat kurangnya investasi pada infrastruktur dan kepadatan penduduk yang tinggi (World Bank Group, 2016). Pembangunan perkotaan terhalang oleh lemahnya institusi pasar lahan, kurang baiknya perencanaan penggunaan lahan aktif, dan rendahnya investasi bidang infrastruktur (Henderson, Kuncoro, \& Nasution, 1996). Selain itu juga terdapat isu lemahnya koordinasi manajemen lahan, peraturan dan pendekatan yang kaku, belum optimalnya sistem perpajakan, serta kurangnya data dan informasi tentang lahan di perkotaan (Firman, 2004). Artinya, permasalahan komuter perkotaan tidak semata-mata terkait dengan perubahan struktur perkotaan, namun juga berhubungan dengan institusi politik dan tata kelola yang terdapat pada teritorial tersebut.

Sebagai wilayah perkotaan yang berkembang sepanjang jejaring kerjasama fungsi sosial dan ekonomi, secara kewilayahan metropolitan terbagi atas beberapa unit adminsitrasi atau politik. Namun secara konsep metropolis terlepas dari batasan-batasan institusional entitas sub-nasional lainnya. Oleh karena itu, tata kelola metropolitan cenderung memiliki karakteristik yang terfragmentasi sehingga sangat rentan terhadap kesulitan dalam manajemen permasalahan lintas wilayah. Berkaitan dengan persoalan desentralisasi, lemahnya tata kelola oleh pemerintah telah membuka ruang yang sangat luas bagi privatisasi dan kontrol oleh swasta sebagai pemerintah bayangan dalam pembangunan di kawasan Jabodetabek (Firman \& Fahmi, 2017; Hudalah, 2017). Berbagai persoalan tersebut menghasilkan segregasi baik pekerjaan maupun spasial pada transformasi kawasan peri-urban Jabodetabek (Winarso, Hudalah, \& Firman, 2015).

Tulisan ini bertujuan untuk mengetahui pendekatan institusi metropolitan yang paling tepat dalam mengatasi permasalahan komuter. Pertanyaan yang diajukan adalah pendekatan reformasi metropolitan apa yang mampu digunakan untuk menyelesaikan permasalahan tersebut. Untuk itu pembahasan dilakukan dalam lima bagian. Pada bagian pertama diungkapkan latar belakang pengaruh tata kelola metropolitan terhadap persoalan komuter. Pada bagian kedua diungkapkan 
mengenai metropolitan, pemasalahan yang melingkupinya dan pendekatan yang dapat digunakan untuk menyelesaikannya. Pada bagian ketiga diungkapkan gambaran mengenai metropolitan Jabodetabek dan masalah komuter yang terjadi di dalamnya. Pada bagian keempat, diungkapkan bagaimana kemungkinan penerapan masing-masing pendekatan dalam menyelesaikan persoalan komuter. Pada bagian kelima diberikan kesimpulan. Seluruh data yang disajikan berasal dari hasil Survei Komuter 2014 dan data lain yang berasal dari BPS kecuali disebutkan lain.

\section{B. REFORMASI METROPOLITAN}

Kawasan metropolitan merupakan Kawasan perkotaan yang terpisah secara administrasi tetapi terhubung secara spasial dan terdiri dari pusat kota dan wilayah sekitarnya (Heinelt \& Kübler, 2005). Ketiadaan institusi yang memayungi kawasan metropolitan tidak mencegah terbentuknya kebijakan metropolitan lintas daerah. Sebagian besar kebijakan tersebut dapat dibentuk melalui kerjasama berbasis isu teritorial yang dihadapi bersama. Mekanisme tersebut disebut Lefèvre (1998) sebagai tata kelola metropolitan, yaitu berbagai jenis kerjasama dalam kawasan metropolitan yang fleksibel dan berorientasi tujuan, yang melibatkan pemerintah lokal dan berbagai tingkatan institusi pemerintahan lainnya serta sektor swasta. Heterogentitas latar belakang dan kompetensi aktor yang terlibat mendorong kebijakan yang dihasilkan agar bersifat independen terhadap batasan yang dimiliki institusi lokal. Mekanisme tata kelola semacam ini menjadi salah satu bentuk yang banyak digunakan dan dipandang sebagai cara yang efektif dalam menyelesaikan permasalahan metropolitan.

Tata kelola metropolitan berkembang dan diperdebatkan berdasarkan dua hal (Tarko, 2015). Pertama mengenai filosofi tatanan sosial yang dibentuk menggunakan konsep polisentrisme. Kedua, terkait fakta empiris bagaimana relevansi tata kelola metropolitan dalam paradigma polisentrisme. Alasan keterlibatan berbagai aktor dan institusi tersebut merupakan campuran antara kemampuan teknis, kemampuan kontrol sumber daya finansial, dan perbedaan kepentingan. Karena tujuan dari tata kelola metropolitan adalah menyelesaikan suatu permasalahan dengan efisien, maka terdapat pertanyaan mengenai kualitas demokrasi yang dihasilkan. Hal ini dikarenakan, penekanan keterlibatan para aktor terletak pada implementasi kebijakan sehingga berjarak dengan legitimasi proses demokrasi yang seharusnya dijalankan. Di negara modern, representasi dan partisipasi terhubung secara kuat pada satruktur teritorial dari institusi politik. Jika tata kelola memungkinkan terciptanya kebijakan metropolitan yang efisien tanpa melibatkan struktur institusi teritorial, maka tidak terdapat kejelasan bagaimana demokrasi yang ada akan terpengaruh.

Reformasi metropolitan memiliki dua tradisi pendekatan tata kelola kawasan metropolitan yang saling bertolak belakang (Ostrom, 1972). Tradisi pertama hadir lebih awal, berpendapat bahwa kawasan metropolitan harus dikelola secara terkonsolidasi. Tradisi kedua merupakan pendekatan yang dominan digunakan pada abad ke-20 lebih menekankan kepada pentingnya pilihan publik sehingga adanya fragmentasi tata kelola dianggap dapat memberikan hasil lebih baik. Pendekatan secara konsolidasi atau neoprogresif dipandang tidak efisien dan 
kurang memberikan dampak langsung terhadap perbaikan kualitas pelayanan kepada masyarakat. Sementara itu, kritik terhadap tata kelola yang terfragmentasi ditujukan kepada kapasitasnya dalam mengatasi masalah metropolitan yang bersifat lintas batas.

Sejalan dengan proses globalisasi, pendekatan tata kelola kawasan metropolitan tersebut kemudian berkembang menjadi empat jenis (Mardianta et al, 2016). Pertama, the metropolitan reform tradisi, yaitu melalui konsolidasi daerah administrasi yang ada dikawasan metropolitan. Kedua, the pilihan publik prespective, yaitu mendorong terjadinya kompetisi antar daerah yang ada di kawasan metropolitan melalui fragmentasi tata kelola. Pendekatan ketiga dikenal sebagai regionalisme baru. Pendekatan ini berfokus pada upaya meningkatkan kemampuan metropolitan berkompetisi secara global dengan mendorong peningkatan koordinasi ekonomi antara kota utama dan suburban untuk mengurangi kesenjangan kesejahteraan. Pendekataan keempat, reterritoriallisation dan rescaling, yaitu transformasi susunan dan skala institusi negara sesuai dengan kebutuhan dan kepentingan tata kelola metropolitan (van der Heiden et al, 2013).

Adanya fragmentasi tata kelola pada pendekatan pilihan publik, dianggap melahirkan kesenjangan antar daerah sehingga melahirkan pendekatan ketiga yaitu regionalisme baru. Jika pendekatan pilihan publik memiliki karakteristik yang menganggap metropolitan sebagai versi pasar bebas dari ekonomi neo klasik, maka regionalisme baru memiliki karakteristik yang berbeda (Wheeler, 2002). Pertama, lebih berfokus kepada teritorial yang spesifik dan perencanaan spasial. Kedua, merupakan bentuk tanggapan atas permasalahan region metropolitan posmodern. Ketiga, merupakan pendekatan holistik yang mengintegrasikan kekhususan perencanaan sebagaimana halnya persoalan lingkungan, kesamaan, dan tujuan ekonomi, Pendekatan holistik yang dimaksudkan terkait dengan mengintegrasikan perencanaan secara tradisional, baik didalam region, antar skala yang berbeda, dan berada dalam konteks sejarah region maupun evolusinya. Keempat, Menekankan kepada perencanaan secara fisik, desain perkotaan, dan perasaan terhadap tempat. Kelima, bersifat lebih aktif dan normatif. Metropolitan region dalam hal ini diasumsikan bukan sebagai kumpulan ekonomi lokal yang saling bersaing, melainkan sebagai suatu kesatuan kawasan ekonomi yang saling melengkapi.

Meskipun dinilai penting dalam meningkatkan daya saing di era globalisasi, pendekatan regionalisme baru tidak terlepas dari adanya kritik. Menurut Brenner (2003), pendekatan regionalisme baru tidak mampu mengatasi terjadinya goncangan dalam ekonomi, dan tidak memiliki landasan politik yang kuat. Dengan kata lain pengambilalihan kebijakan ekonomi pada tingkat regional dengan menepikan peran pemerintah adalah tidak tepat, karena ruang politik nasional merupakan penentu utama yang dapat menengahi kebutuhan akan persaingan dan kesejahteraan. Untuk mengatasinya, peran pemerintah dalam tata kelola region dipandang perlu untuk dipulihkan melalui kehadiran agen pemerintah pada teritorial tertentu atau skala yang lebih kecil. Dengan demikian pemerintah lokal atau regional tidak lagi bertindak sebagai agen yang mengelola program yang bersifat nasional, namun lebih bertindak sebagai agen yang mengusahakan pembiayaan oleh negara melalui keunggulan lokasinya dalam 
konteks kompetisi global (Brenner, 1999). Namun hal ini juga mendapatkan kritik dari van der Heiden et al (2012), yang menyatakan bahwa tantangan globalisiasi yang dihadapi oleh setiap region berbeda-beda. Maka, peran terbesar dalam keberhasilan pendekatan ini terletak pada sejauh mana pemahaman aktor terhadap tantangan globalisasi yang dihadapi.

Besarnya ukuran metropolitan diikuti dengan konsentrasi ekonomi dan politik yang tinggi sehingga menyebabkan munculnya berbagai permasalahan kompleks terkait dengan pembangunan lintas wilayah yang memiliki tata kelola berbeda. Secara umum permasalahan yang dihadapi kawasan metropolitan dapat dibagi menjadi dua golongan besar. Pertama, masalah kesenjangan pemerintah pada strata sosial (social stratification-government inequality/SSGI) yang dikemukakan oleh Hill (1974). Institusi yang terfragmentasi dipandang justru mendorong terciptanya kesenjangan pendapatan antar wilayah dalam kawasan metropolitan melalui ketidaksesuaian antara sumber daya dan kebutuhan yang berlangsung secara sistematis. Permasalahan kedua, dimunculkan oleh kalangan regionalisme baru yang berpendapat bahwa pemerintah lokal yang terfragmentasi memiliki posisi yang kurang baik dalam mengatasi masalah perumahan, lingkungan, dan transportasi yang berkaitan dengan urban sprawl (Rusk, 1995). Menurut Sellers dan Hoffmann-Martinot (2008), beberapa permasalahan tersebut terjadi karena:

1. Ketidakhadiran panduan dan kontrol teritorial

Sebaran perkotaan dapat dibatasi hanya melalui tindakan kerjasama antara wilayah perkotaaan yang terdampak;

2. Kurangnya konsultasi struktural untuk memecahkan permasalahan bersama Ketika struktur ekonomi dalam wilayah metropolitan saling terhubung, maka suatu keputusan yang diambil oleh tata kelola yang terfragmentasi akan mempengaruhi daerah sekitarnya. Untuk itu, tata kelola metropolitan tidak hanya tindakan kolektif secara horizontal namun juga memerlukan hubungan secara vertikal.

Tabel 1. Perbandingan kelebihan dan kekurangan pendekatan reformasi metropolitan

\begin{tabular}{|c|c|c|}
\hline Pendekatan & Kelebihan & Kekurangan \\
\hline Konsolidatif & 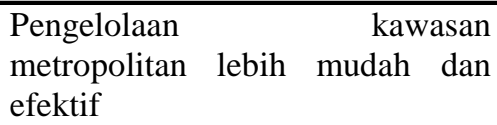 & $\begin{array}{l}\text { Membutuhkan dukungan politik yang } \\
\text { besar karena rentan menimbulkan } \\
\text { resistensi dari elit politik lokal }\end{array}$ \\
\hline $\begin{array}{l}\text { Perspektif pilihan } \\
\text { publik }\end{array}$ & $\begin{array}{l}\text { Mendorong terciptanya kualitas } \\
\text { pelayanan publik yang lebih baik }\end{array}$ & $\begin{array}{l}\text { Kegagalan dalam berkompetisi akan } \\
\text { memperbesar ketimpangan antar } \\
\text { wilayah }\end{array}$ \\
\hline $\begin{array}{l}\text { Regionalisme } \\
\text { baru }\end{array}$ & $\begin{array}{l}\text { Mengurangi ketimpangan dan } \\
\text { kompetitif secara global }\end{array}$ & $\begin{array}{l}\text { Memotong peran negara dan dibangun } \\
\text { tanpa landasan politik yang kuat }\end{array}$ \\
\hline $\begin{array}{l}\text { Rescaling and } \\
\text { reterritoriallisation } \\
\text { approach }\end{array}$ & $\begin{array}{l}\text { Mampu menghadirkan regulasi } \\
\text { dan investasi negara yang } \\
\text { diperlukan untuk meningkatkan } \\
\text { daya saing }\end{array}$ & $\begin{array}{l}\text { Sangat bergantung kemampuan aktor } \\
\text { pengambil kebijakan untuk memahami } \\
\text { tantangan globalisasi yang dihadapi }\end{array}$ \\
\hline
\end{tabular}

Sumber: hasil interpretasi

Oleh para pendukung tata kelola terfragmentasi, perdebatan terkait hal ini lebih ditekankan kepada seberapa efektif solusi yang diberikan. Mereka berpendapat bahwa solusi terbaik akan didapatkan melalui persetujuan atau 
kerjasama antar tata kelola terkait di dalam wilayah yang terdampak (Ostrom, 1972). Namun para pendukung pendekatan neoprogresif telah membuktikan bahwa tata kelola secara polisentris yang efektif pada institusi terfragmentasi akan sulit diwujudkan apabila terdapat biaya transaksi, konflik kepentingan, dan penyimpangan preferensi dalam mengadopsi kebijakan yang tinggi. Sersebut sulit untuk berhasil dan dipandang justru dapat mendorong terjadinya tragedy of the commons (Lowery, 1998). Sementara itu, bukti yang tersedia justru menunjukan bahwa permasalahan sprawl and redistribusi pendapatan memiliki dampak yang lebih ringan jika ditangani oleh bentuk tata kelola yang terkonsolidasi (Rusk, 1995). Kelebihan dan kekurangan masing-masing pendekatan diberikan pada tabel 1. Pemilihan paradigma yang diterapkan tergantung pada kondisi politik masing-masing negara atau kontekstual (Salet et al, 2003).

\section{PERMASALAHAN KOMUTER PERKOTAAN}

Hubungan antara penggunaan lahan dan pola komuter perkotaan dapat dikategorikan kedalam tiga topik yang saling berkaitan: keseimbangan rumahtempat kerja, excess commuting, dan aksesibilitas (Horner, 2004). Beberapa penelitian sebelumnya terkait keseimbangan lokasi rumah dan tempat kerja antara lain pernah dilakukan oleh (Giuliano \& Small, 1993) dan (Zhao, Lü, \& Roo, 2011). Keduanya menghasilkan kesimpulan yang serupa dimana keseimbangan antara lokasi rumah dan tempat kerja memiliki pengaruh yang negatif dan signifikan. Namun (Giuliano \& Small, 1993) berargumen bahwa pengaruh yang dihasilkan tidak terlalu besar dalam menjelaskan variasi waktu komuter, sehingga Intervensi kebijakan untuk mengatasi permasalahan komuter melalui pengaturan penggunaan lahan tidak akan memberikan dampak yang berarti.

Beberapa kesimpulan yang dapat diperoleh berdasarkan penelitian-penelitian terkait excess commuting antara lain: (1) Perilaku spasial yang sesungguhnya memiliki kecenderungan melewati nilai minimal, namun pada derajat tertentu menoleransi adanya excess commuting; (2) Metropolitan yang berukuran lebih besar menghasilkan excess commuting yang lebih tinggi, namun pola komuternya lebih efisien; (3) Perilaku komuter tidak selalu mengikuti bentuk perkotaan; (4) Dengan adanya desentralisasi, pekerjaan durasi komuter justru semakin meningkat; (5) Tidak terdapat indeks terbaik untuk pengukuran efisiensi komuter, masing-masing memiliki kelebihan dan kekurangan. setiap indeks ditujukan untuk menjawab pertanyaan yang berbeda; (6) Suatu kota dikatakan memiliki komuter yang seimbang apabila bentuk kota seimbang (minimum commuting rendah), dan perilaku pilihan lokasi tempat tinggal sesuai dengan bentuk perkotaan (excess commuting rendah); (7) Penduduk dengan pilihan lebih baik memiliki tingkat excess commuting lebih tinggi.

Pada penelitian terkait aksesibilitas, (Camagni et al., 2002) melakukan pengukuran relevansi struktur perkotaan dalam menentukan biaya sosial dan lingkungan melalui konsumsi lahan serta pola mobilitas di Metropolitan Milan, Italia. Hasilnya didapati bahwa efisiensi dan daya saing transportasi publik sangat dipengaruhi oleh struktur organisasi wilayah perkotaan. Struktur sprawl memiliki kontribusi paling rendah dalam penggunaan transportasi publik. Penelitian lainnya oleh (Engelfriet \& Koomen, 2017) mendapati bahwa (1) pola komuter 
memberikan reaksi berbeda terhadap bentuk urban yang berbeda; (2) Keberadaan cluster bisnis/ perumahan memegang peranan dalam menjelaskan pola komuter; dan (3) Rasio jumlah kendaraan umum terhadap penduduk, serta, struktur yang polisentris atau penggunaan lahan campuran tidak mempengaruhi durasi komuter.

Dari berbagai penelitian terkait hubungan antara pengaruh struktur spasial perkotaan terhadap pola mobilitas tersebut dapat disimpulkan bahwa komuter mempengaruhi performa sistem transportasi perkotaan secara signifikan. Meningkatnya komuter disebabkan oleh terpisahnya fungsi secara fisik akibat bentuk kota pada derajat tertentu, durasi komuter dipengaruhi oleh pemisahan spasial antara rumah dan tempat kerja serta oleh struktur perkotaan. Namun berbagai bukti empiris yang disajikan masih menunjukkan tingginya unsur ketidakpastian atas hubungan kedua unsur tersebut. Beberapa hal yang dinilai perlu menjadi perhatian diantaranya adalah: (1) Apakah struktur kota sudah bersifat polisentris, atau masih berada dalam masa transisi?; (2) Apakah hubungan antara pusat dan sub pusat bersifat independen?; (3) Apakah pekerjaan mengikuti populasi atau sebaliknya?; (3) Bagaimana variasi pola komuter didalam dan antar metropolis?; dan (4) Bagaimana pengaruh aktor dan institusi pada pola alokasi tempat tinggal yang mempengaruhi komuter?. Selain itu, pengaruh pemilihan lokasi rumah terhadap pola komuter juga masih belum mendapatkan banyak perhatian (Giuliano \& Small, 1993).

Interaksi antara bentuk urban dan perilaku perjalanan ditentukan oleh empat hal yaitu: organisasi spasial permukiman, kebijakan spasial, konteks ekonomi domestik, serta norma dan nilai budaya masyarakat (Schwannen et al, 2002). Selama ini, penelitian pola perjalanan yang berkaitan dengan organisasi spasial (mis: Buliung dan Karanoglou, 2002), ekonomi domestik (mis: Borck et al, 2010), serta norma di masyarakat (mis: Ding et al, 2017) telah banyak dilakukan. Namun demikian, dalam keterkaitannya atas konteks kebijakan spasial, penelitian tentang bentuk perkotaan dan pola perjalanan masih belum mendapat banyak perhatian. Beberapa penelitian (misal: Zhao, et al, 2011) menemukan bahwa liberalisasi regulasi yang didasarkan oleh kekuatan pasar berdampak negatif terhadap upaya mengatasi excess commuting. Pada kasus di Beijing tersebut, pengaruh liberalisasi regulasi sangat terkait dengan perubahan bentuk kota akibat terjadinya urban sprawl.

Dalam konteks Indonesia, kelemahan dalam regulasi tersebut diyakini memiliki keterkaitan dengan kompleksitas tata kelola perkotaan terhadap upayaupaya untuk meningkatkan keterhubungan serta mobilitas yang sifatnya berkelanjutan. Hingga saat ini, isu kemacetan di Jakarta telah mencapai tahap yang mengkhawatirkan dimana pada tahun 2020 potential loss diperkirakan mencapai 65 Triliun Rupiah (Harmadi et al, 2015). Meskipun belum terdapat penelitian mengenai excess commuting di JMA, namun situasi ini jelas mengindikasikan tingginya ketidakseimbangan pada lokasi rumah dan tempat bekerja. Padahal jika ditinjau dari sisi kelembagaan, perangkat yang ada dinilai telah cukup memadai. Perencanan kebijakan spasial di kawasan ini diketahui diatur secara terintegrasi melalui PP 54 Tahun 2008 dan dilembagakan dalam Badan Kerjasama Pembangunan (BKSP) yang telah terbentuk sejak tahun 1975. 
Proses desentralisasi kekuasaan telah menghadirkan tantangan baru, dimana keterbatasan kemampuan pemerintah lokal dalam membangun jaringan kerjasama dengan pemerintah disekelilingnya dimanfaatkan oleh sektor privat untuk mengubah struktur dan pola spasial. Dalam kasus di JMA, kondisi ini menyebabkan pembangunan infrastruktur yang seharusnya dapat dilakukan secara komprehensif untuk meningkatkan keterhubungan antar wilayah justru menyebabkan terjadinya fragmentasi antar daerah (Hudalah, 2017). Fragmentasi tersebut tercermin dalam pola komuter yang terjadi di wilayah JMA.

\section{Asal dan tujuan perjalanan yang tidak teratur}

Sebagai pusat kegiatan ekonomi yang berbasis jasa dan keuangan, wilayah DKI Jakarta khususnya di Jakarta selatan dan Jakarta Pusat masih menjadi tujuan perjalanan komuter yang dominan. Namun perlu disadari bahwa sejalan dengan terjadinya desentralisasi, kegiatan komuter di kawasan Jabodetabek tidak lagi terpusat di kedua wilayah tersebut, melainkan telah terjadi peningkatan arus komuter baik dari DKI Jakarta menuju kawasan Bodetabek, maupun antar kabupaten kota di wilayah Bodetabek. Data hasil Survei Komuter tahun 2014 menunjukkan bahwa 39 persen atau 1,3 juta dari 3,5 juta komuter di Jabodetabek masih melakukan kegiatan komuter di Jakarta Selatan dan Jakarta Pusat. Namun jumlah penduduk DKI Jakarta yang melakukan komuter ke wilayah Bodetabek mencapai hampir 250 ribu orang. Sementara itu, 750 ribu penduduk Bodetabek lainnya melakukan komuter antar wilayah Bodetabek. Pola komuter yang semula bersifat monosentris, kini telah bergeser menjadi polisentris. Meskipun masih berada pada fase awal (Hudalah et al, 2013), hal ini perlu disikapi dengan serius oleh seluruh pemerintah daerah di Jabodetabek.

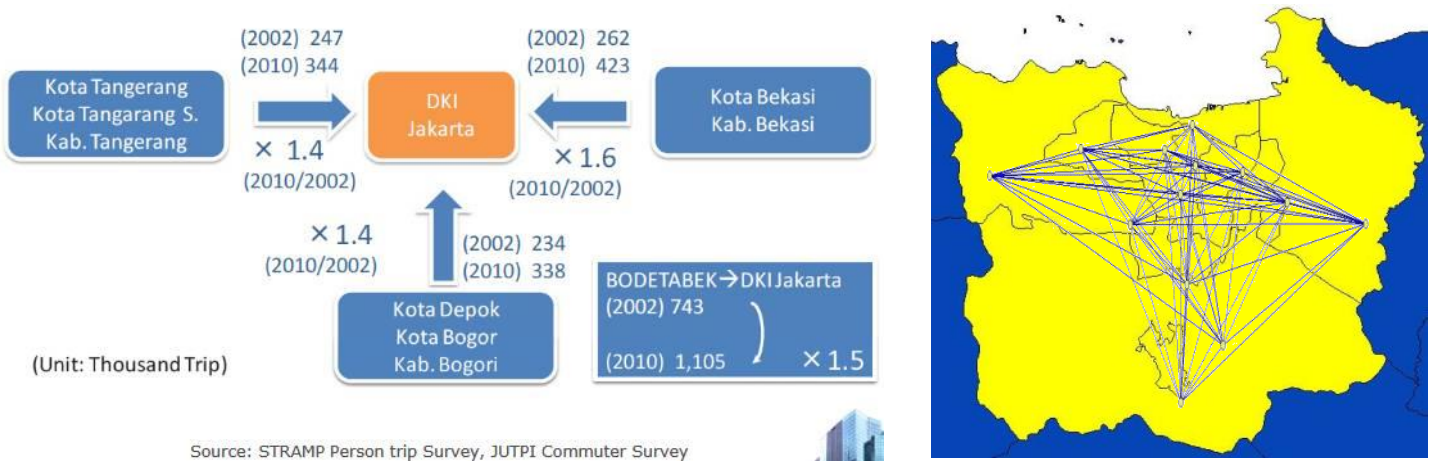

Gambar 1. Perubahan pola perjalanan komuter di JMA (2002-2010, dan 2014

\section{Ketidakcocokan permintaan dan penawaran sistem transportasi}

Dari sisi penawaran, sudut pandang perencanaan yang dipergunakan masih bersifat monosentris dimana wilayah DKI Jakarta menjadi pusat segala kegiatan. Oleh karena itu jaringan jalan yang tersedia sebagian besar diarahkan menuju, atau melewati wilayah DKI Jakarta. Rute paling singkat dari Kabupaten Bekasi menuju Kabupaten Tangerang dan sebaliknya adalah melewati jalan tol lingkar dalam Jakarta. Akibatnya seluruh beban perjalanan bertumpu pada lokasi tersebut dan menyebabkan kemacetan. 


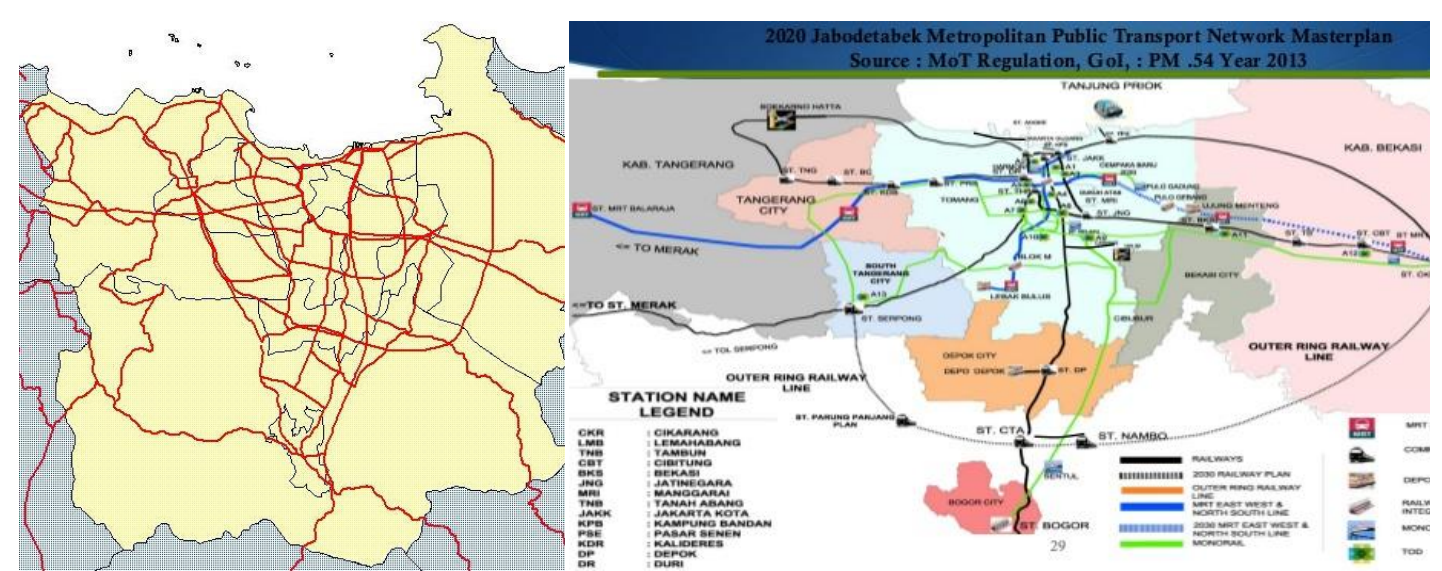

(a)

(b)

Gambar 2. Perbandingan (a) ketersediaan Jaringan Jalan dan (b) rencana pembangunan jaringan transportasi publik di JMA Sumber: Kementerian Perhubungan

Dari segi permintaan terjadi ketidakcocokan dimana 56 persen perjalanan komuter di wilayah ini dilakukan dengan menggunakan sepeda motor. Dibandingkan perjalanan menggunakan mobil pribadi yang hanya sebesar 11 persen, hal ini tentu perlu menjadi perhatian karena pembangunan infrastruktur selama ini dilakukan dengan mengedepankan kebutuhan perjalanan bermobil. Dari sisi keamanan, perjalanan menggunakan sepeda motor juga dinilai memiliki resiko yang lebih tinggi.

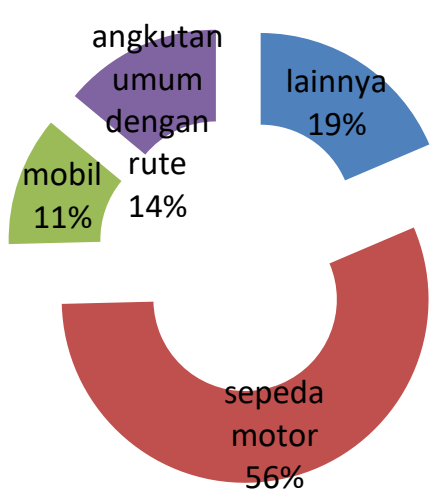

(a)

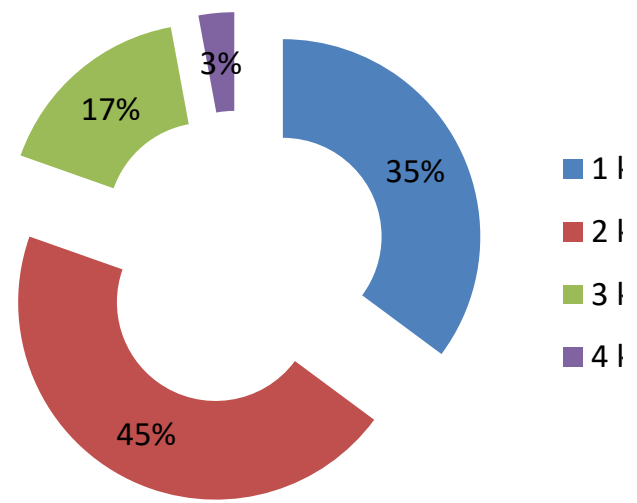

(b)

Gambar 3. Perbandingan (a) pilihan moda komuter dan (b) banyaknya pergantian moda di JMA 2014

Diperlukan upaya untuk mendorong perjalanan menggunakan angkutan umum reguler yang tingkat okupansinya baru mencapai 14 persen. Upaya tersebut perlu dilakukan secara terintegrasi mengingat 65 persen perjalanan dengan angkutan umum reguler tersebut dilakukan dengan berganti moda sebanyak dua kali atau lebih. Kegagalan satu daerah penyangga menyediakan angkutan umum yang terintegrasi dengan wilayah DKI Jakarta akan menyebabkan komuter lebih memilih untuk menggunakan kendaraan pribadi. 


\section{Pendekatan Reformasi Metropolitan Dalam Isu Komuter}

Kawasan metropolitan bukan bagian dari struktur tata kelola yang ada di Indonesia, sehingga upaya untuk memasukkan konsep ini membutuhkan dukungan politik yang sangat besar. Rencana pembangunan kawasan metropolitan harus terintegrasi secara vertikal, meskipun sudah diakomodir dalam UU 26 tahun 2007 namun implementasinya sangat tergantung pada kebijakan lokal. Implementasi pembangunan dan pengendalian kawasan ini masih terbagi pada setiap tingkatan tata kelola sesuai dengan kewenangannya. Perencanaan kawasan metropolitan yang dibuat pada skala nasional belum menjadi alat koordinasi bagi setiap tingkatan pemerintah. Akibatnya penataan ruang dan penyediaan fasilitas pelayanan umum tertentu secara lintas wilayah yang semestinya dikelola secara bersama dalam prakteknya sulit dilakukan karena keterbatasan pembiayaan. Untuk itu kebijakan internalisasi pengelolaan kawasan metropolitan menjadi sangat penting, namun perlu tetap melekat pada struktur yang ada. Model-model pengelolaan bersama dan penguatan kapasitas daerah perlu dikedepankan dalam pengelolaan kawasan metropolitan (Mardianta et al, 2016).

\section{Pendekatan Konsolidatif}

Sistem tata kelola DKI Jakarta merupakan suatu bentuk anomali dari UU desentralisasi. Ketika UU tersebut memberikan kekuasaan pengambilan kebijakan yang begitu besar pada tingkat kabupaten dan kota di 33 provinsi lain, yang terjadi di wilayah ini justru sebaliknya. Status sebagai daerah khusus ibukota menjadikan kekuasaan terbesar perencanaan dan pengendalian pembangunan perkotaan justru berada di tangan gubernur. Posisi kabupaten dan kota dalam situasi ini tidak ubahnya seperti unit pelaksana teknis yang melaksanakan kebijakan provinsinya. Pada awalnya regulasi yang mengatur provinsi DKI Jakarta tersebut didesain dengan mengakomodasi prinsip-prinsip tata kelola metropolitan yang terkonsolidasi. Sebagai hasilnya, proses pengambilan kebijakan lintas kabupaten kota di wilayah ini berjalan dengan terintegrasi sehinggan menjadikannya sebagai derah yang maju dan berkembang dengan pesat. Namun ketika wilayah yang tersedia tidak lagi mampu menampung pertumbuhan perkotaan, maka terjadi ekspansi melewati wilayah kewenangannya. Pembangunan infrastruktur transportasi yang semula ditujukan untuk mendukung pertumbuhan DKI Jakarta justru menjadi pendorong bagi perluasan fungsi perkotaan.

Pertumbuhan perkotaan selalu diawali oleh pertumbuhan populasi. Hal ini kemudian diikuti dengan perluasan wilayah untuk dapat menyediakan lahan bagi permukiman dan aktivitas ekonomi. Pada saat yang sama, perkembangan teknologi transportasi dan komunikasi telah meningkatkan mobilitas penduduk. Sebagaimana karakteristik negara berkembang lainnya, pemisahan yang jelas antara perkotaan dan perdesaan tidak dapat dilakukan, struktur yang unik ini dikenal sebagai region desakota. Saat ini populasi DKI Jakarta sendiri telah mencapai lebih dari 10 juta jiwa. Data BPS tahun 2016 menunjukkan bahwa jika dikombinasikan dengan kawasan Bodetabek, maka jumlah penduduk keseluruhan mencapai 32,5 juta jiwa atau 12 persen dari penduduk nasional. Secara fungsional kawasan metropolitan Jabodetabek telah meliputi tiga provinsi dan 13 Kabupaten Kota. 


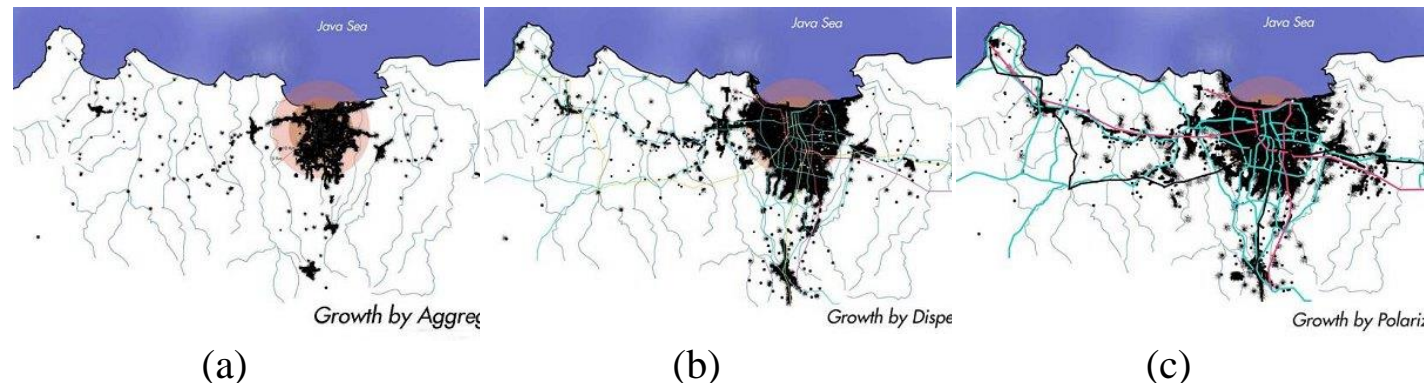

Gambar 4. Perkembangan Jakarta Metropolitan Area menurut (a) agregat, (b) dispersi,

(c) polarisasi

Sumber: Pereshtu (2002)

Dengan semakin banyak dan beragamnya aktor yang terlibat, pendekatan konsolidatif seperti dilakukan di DKI Jakarta tidak dapat lagi diterapkan karena wilayah yang perlu dikelola telah melampaui batas wilayah kewenangannya. Upaya untuk memperluas pengelolaan secara konsolidatif akan sangat sulit dilakukan mengingat rencana tata ruang dan tata wilayah yang ada saat ini tidak dapat memberikan kepastian mengenai seberapa besar metropolitan akan berkembang. Dalam konteks penanganan komuter, membesarnya kawasan fungsional metropolitan juga menjadi semakin sulit karena diikuti dengan perubahan bentuk urban. Pola perjalanan yang semula bersifat monosentris menuju core di Jakarta, di masa depan akan semakin melebar dan saling terjadi komuter silang. Jabodetabek saat ini menjadi suatu mega urban region yang besarnya diperkirakan akan terus mengalami perluasan seiring dengan berkembangnya koridor transportasi.

\section{Pendekatan Regionalisme Baru}

Sejalan dengan proses desentralisasi di Indonesia, perencanaan pembangunan di wilayah regional metropolitan mendapatkan perhatian dari berbagai pihak. Kebijakan desentralisasi melalui UU 22 Tahun 1999 dan diperbarui dengan UU No. 32 tahun 2004 telah mengubah wajah perencanaan spasial Indonesia dari yang semula bersifat terpusat dan berjenjang (vertikal) menjadi semakin horizontal. Melalui regulasi tersebut pemerintah daerah mendapatkan peran kekuasaan yang semakin besar (Firman, 2009). Di sisi lain, pemerintah pusat dan provinsi seperti kehilangan peran dalam proses perencanaan tingkat lokal dan regional. Akibatnya, tanggungjawab perencanaan pembangunan pada skala metropolitan mengalami kekosongan. Untuk mengatasi permasalahan tersebut, pemerintah pusat membentuk Badan Koordinasi Penataan Ruang Daerah melalui Permendagri 50 Tahun 2009 pada tingkat provinsi. Namun demikian, proses perencanaan pembangunan pada skala metropolitan hingga saat ini masih belum dapat berjalan sebagaimana mestinya. Hal ini terjadi karena badan perencanaan yang dibentuk tidak diberikan kekuasaan untuk memaksa pemerintah daerah mengimplementasikan paradigma metropolitan dalam perencanaan tingkat lokal (Okitasari \& Kidokoro, 2012).

Desentralisasi di Indonesia berdampak pada meningkatnya ego lokal akibat celah institusi pada tingkat regional dan dorongan pemerintah daerah untuk berkonsentrasi ke dalam (Firman, 2009). Situasi ini menciptakan paradoks bagi tata kelola kawasan metropolitan. Pada satu sisi, desentralisasi memberikan 
peluang bagi pemerintah daerah untuk saling berkolaborasi, namun pada sisi lain terdapat kecenderungan euforia otonomi daerah yang membatasi perspektif perencanaan pada batas wilayah administratifnya. Salah satu bentuk kolaborasi tingkat metropolitan yang banyak dijadikan pembelajaran adalah pengelolaan sampah di Kartamantul (Yogyakarta, Sleman, dan Bantul). Namun pembelajaran yang didapatkan dari kasus tersebut tidak serta merta dapat segera diduplikasi karena adanya perbedaan dalam terbentuknya institusi.

Firman (2014) dalam penelitiannya mengenai perbandingan pengelolaan sampah di Jabodetabek dan Kartamantul menyoroti bahwa perbedaan paling utama terdapat dalam hal inisiatif kolaborasi. Di Kartamantul kolaborasi terjadi karena adanya kesadaran bersama untuk menyelesaikan permasalahan sampah, sehingga inisatif yang berasal dari bawah (bottom up) dinilai lebih efektif. Di Jabodetabek, kolaborasi dikelola oleh Badan Kerjasama Pembangunan (BKSP) dengan melibatkan pemerintah pusat. Artinya inisiatif berasal dari pusat, dan pemerintah daerah diminta untuk berkontribusi didalamnya (top Down). Pada pendekatan bottom up, meskipun terdapat beberapa kasus keberhasilan namun jumlahnya hanya sedikit. Hal ini menunjukkan bahwa upaya membangun inisiatif dari bawah merupakan hal yang sangat sulit dan sulit diwujudkan tanpa kehadiran pemerintah pusat. Dalam kasus Kartamantul, selain ukuran metropolitan yang kecil, jumlah aktor yang sedikit, kesamaan pandangan dan budaya, serta adanya peran pemerintah provinsi sebagai mitra ikut mempengaruhi keberhasilannya. Pada kasus Jabodetabek, meskipun model kerjasama ini telah dapat diterima oleh semua pihak, namun dipandang kurang efisien karena sangat bergantung pada insentif maupun disinsentif yang tersedia. Hal ini menunjukkan bahwa pendekatan yang sedang digunakan ini perlu diperbaiki.

Secara normatif, proses kolaborasi memerlukan prasyarat antara lain adanya kedudukan setara antar pihak yang terlibat dalam komunikasi (Innes \& Booher, 2010). Dalam kasus komuter, kolaborasi yang dihasilkan memerlukan biaya transaksi yang besar akibat akibat ketidaksetaraan kedudukan para aktor di dalamnya. Pada prosesnya Provinsi DKI Jakarta yang diwakili gubernur dinilai sebagai pihak yang memiliki daya tawar yang lebih rendah dari berbagai sisi. Pertama, tidak ada kekuasaan serta kurangnya perhatian dari pemerintah provinsi Jawa Barat dan Banten. Saat ini, pemerintah kabupaten kota di sekitar Jakarta cenderung berlomba-lomba untuk menampung limpahan penduduk dan pekerjaan dari Jakarta. Namun di sisi lain, mereka tidak memiliki sumber daya yang cukup untuk mengelola pembangunan tersebut. Kedua, daerah penyangga DKI Jakarta tidak memiliki pandangan yang sama mengenai perkembangan komuter sebagai isu bersama. Wilayah penyangga masih dianggap sebagai kawasan tempat tinggal yang tidak mengalami masalah kemacetan dan polusi. Padahal kedepannya, kemacetan dan polusi akan semakin merata di seluruh wilayah sejalan dengan semakin meratanya pertumbuhan ekonomi. Penerapan regionalisme baru yang sudah berjalan selama ini di Jabodetabek sulit diharapkan untuk dapat menyelesaikan masalah komuter kecuali terdapat kesetaraan antar aktor yang terlibat. 


\section{Pendekatan Rescalling dan Reteritorialization}

Metropolitan region terdiri atas satu komunitas besar yang terintegrasi baik secara sosial maupun ekonomi. Bagaimanapun, metropolitan region tidak memiliki identitas administrasi tunggal, melainkan terdiri atas agensi pemerintah pusat dan lokal yang memiliki kekuasaan terpisah, namun saling terkait satu sama lain. Situasi ini membuat administrasi yang efisien menjadi tidak dimungkinkan karena setiap aktor tersebut bertindak sesuai autarki sehingga tidak mampu menampilkan fungsi yang seharusnya. Tanpa adanya pusat koordinasi, setiap pemerintahan lokal akan bertindak sesuai kepentingannya tanpa memperhatikan kepentingan publik (Ostrom, 1972). Hal ini kemudian mengerucut kepada ide bahwa permasalahan pemerintahan metropolitan terletak pada jumlah pemerintah yang terlalu banyak, namun kemampuannya tidak terlalu baik sehingga menghasilkan duplikasi fungsi, kewenangan yang saling tumpang tindih, dan organisasi yang kacau. Pendapat ini mirip dengan apa yang dipikirkan oleh pemikir sosialis mengenai superioritas perencanaan terpusat dibandingkan pasar bebas.

Pendekatan politik ekonomi tidak mengasumsikan bahwa kompetisi antar agensi publik adalah hal yang tidak efisien. Ostrom (1972) menentang asumsi tersebut dengan berpendapat bawa skala produksi optimal untuk setiap jenis layanan dan barang yang diperlukan oleh publik di perkotaan tidak sama. Oleh karenanya, sebagian pelayanan akan dapat diproduksi secara lebih efisien pada skala besar, namun beberapa jenis lainnya akan diproduksi secara lebih efisien pada skala kecil. Oleh karenanya keberadaan agensi yang saling berinteraksi dan tumpang tindih adalah suatu kondisi yang alami dan sehat. Tumpang tindih dan duplikasi agensi merupakan tanggapan dari kebutuhan pelayanan yang berbeda memerlukan skala yang berbeda untuk menghasilkan efisiensi. Hal ini juga terkait dengan pengaruh globalisasi yang dampaknya diterima secara berbeda antar satu wilayah dengan wilayah lain.

Proses rescaling tidak hanya terjadi pada kota global akan tetapi juga kotakota yang memiliki keterkaitan dengan wilayah luar. Melalui rescaling, negara turut hadir dalam bentuk institusi yang sesuai dengan skala permasalahan yang menjadi sasaran. Di Indonesia institusi seperti ini sebenarnya sudah hadir, misalnya dalam bentuk penyelenggaraan jalan tol oleh negara melalui BUMN. Penyelenggaraan jalan tol diatur sepenuhnya secara terpusat dengan lokasi produksi yang melintasi kabupaten kota maupun provinsi dan dapat berlangsung secara profesional sehingga efisien. Pemerintah daerah mendapatkan manfaat dalam bentuk infrastruktur transportasi, penyerapan tenaga kerja, dan sumbangan atas pendapatan. Namun dalam urusan yang diselenggarakan secara non-profit, terdapat prasyarat yang diperlukan untuk mendukung keberhasilannya.

Pada kasus penyelenggaraan bus rapid transit (BRT) di Kawasan metropolitan Mebidang, dukungan dari pemerintah daerah (pemerintah provinsi dan kabupaten/kota) sangat penting untuk memastikan keberhasilan pelaksanaan kebijakan pemerintah pusat di kawasan metropolitan. Bentuk dukungan pemerintah daerah tersebut ditunjukkan mulai dari tahapan perencanaan khususnya dalam pengenalan isu dan potensi persoalan, pemprograman dan keterlibatan sumber daya keuangan daerah. Dalam proses rescaling tersebut, 
pemerintah pusat melakukan penyesuaian program agar dapat terlaksana, pemerintah daerah memastikan program, melibatkan sumber daya daerah baik personil maupun keuangan. Dukungan pemerintah daerah tetap diperlukan untuk membangun rasa kepemilikan dan penerimaan dalam penyelenggaraan programprogram pemerintah pusat di daerah. Kegagalan pengelolaan kawasan metropolitan karena pemerintah pusat tidak memberikan kewenangan yang cukup kepada pemerintah daerah (Mardianta, 2017).

Dalam konteks komuter, perlu dibangun suatu institusi rescaling yang dapat mengakomodasi kepentingan lokal. Dominasi kebijakan pemerintah pusat diwujudkan dalam inisasi untuk membentuk ruang baru, memberikan pertimbangan deliniasi ruang, dan memberikan pemecahan persoalan yang dihadapi oleh kawasan metropolitan. Namun demikian, keberadaan wakil-wakil pemerintah daerah untuk memberikan pemikiran dan dukungan secara institusi tetap diperlukan. Perencanaan perlu dibuat dengan mempertimbangkan aliran komuter masuk dan keluar yang ada, serta kemungkinan perkembangannya di masa yang akan datang. Dengan demikian institusi ini harus berada dibawah koordinasi dari Badan Koordinasi Penataan Ruang, karena sangat berkaitan dengan keberhasilan pencapaian keseimbangan lokasi pekerjaan dan permukiman. Badan koordinasi penataan ruang bukan lagi bersifat kedaerahan, namun sebagai institusi pusat yang skala yurisdiksinya bersifat fleksibel. Artinya ketika luas kawasan fungsional bertambah, maka besarnya kewenangan badan tersebut juga semakin besar. Implikasinya adalah bahwa rencana tata-ruang yang dibuat harus mempertimbangkan potensi permintaan transportasi dan penawaran yang tersedia.

\section{KESIMPULAN}

Isu komuter merupakan persoalan yang terkait dengan keseimbangan antara lokasi pekerjaan dan permukiman. oleh karena itu perencanaan spasial seharusnya ditujukan kepada tercapainya struktur perkotaan yang kompak yang dapat menunjang hipotesis ko-lokasi, yaitu penduduk tinggal di lokasi yang berdekatan. Dengan demikian, pola perjalanan menjadi efisien dan dapat meminimalisir eksternalitas negatif seperti kemacetan dan polusi. Namun, pengaruh globalisasi menyebabkan bentuk kota semakin terdesentralisasi. Bentuk kota yang semula monosentris menjadi semakin polisentris. Lokasi pekerjaan berpindah dari pusat kota ke wilayah suburban sehingga pola perjalanan yang semula bersifat tradisional, dari suburban menuju pusat kota, menjadi semakin rumit. Perjalanan antar suburban maupun dari pusat ke suburban (cross-commuting) semakin meningkat sehingga eksternalitas negatif yang semula berada di pusat kota kini menyebar ke suburban. Hal ini berdampak terhadap excess commuting yang semakin bertambah dan berpengaruh tidak hanya terhadap kondisi ekonomi, melainkan juga kondisi sosial.

Di Indonesia, isu kemacetan dan polusi merupakan permasalahan yang menjadi perhatian utama di metropolitan selain banjir dan ketimpangan sosial. Dalam kerangka metropolitan, permasalahan komuter tradisional dan cross commuting seringkali bersifat lintas batas wilayah. Namun demikian, desentralisasi pekerjaan yang menyebabkan perubahan bentuk kota ternyata juga diikuti oleh desentralisasi kekuasaan. Hal ini menyebabkan perencanaan 
penanganan masalah komuter menghadapi kendala karena tidak terdapat institusi yang memiliki kewenangan untuk menyatukan tata kelola yang terfragmentasi tersebut. Dalam tulisan ini dilakukan analisis terhadap pendekatan penyelesaian isu metropolitan di Indonesia. Dengan mengambil kasus metropolitan Jabodetabek, tulisan ini menekankan pada permasalahan komuter yang dihadapi, serta bentuk reformasi metropolitan yang dapat diadopsi untuk mengatasi masalah tersebut. Saat ini, bentuk metropolitan Jabodetabek dianggap tengah mengambil pendekatan pilihan publik, dimana antar satu daerah dengan daerah lainnya saling bersaing untuk memberikan pelayanan yang terbaik.

Melalui perbandingan antara tiga pendekatan reformasi metropolitan: konsolidatif, regionalisme baru, dan rescaling, dapat diambil beberapa kesimpulan. Pertama bentuk konsolidatif sulit diterapkan di Indonesia, karena metropolitan terus berkembang tanpa ada kepastian akan batasnya. Artinya pola komuter akan terus berkembang dan melibatkan lebih banyak wilayah. Di sisi lain, konsolidasi teritorial akan mendapatkan tantangan dari entitas politik lokal yang merasa kehilangan hak-hak yang dimilikinya. Pendekatan kedua melalui bentuk regionalisme baru, dinilai lebih menjanjikan. Namun hal ini dinilai sulit dicapai karena rendahnya inisiatif setiap institusi yang terlibat. Beberapa pembelajaran sukses seperti pengelolaan sampah di metropolitan Kartamantul juga tidak serta merta dapat diduplikasi di tempat lainnya karena adanya perbedaan konteks serta latar belakang kolaborasi yang dibangun. Sementara itu, rescaling sebagai pendekatan terakhir dianggap paling tepat untuk diterapkan untuk mengatasi permasalahan komuter metropolitan. Melalui intervensi pemerintah pusat, diharapkan permasalahan komuter lintas wilayah dapat diselesaikan dengan lebih baik meskipun diperlukan adanya penyesuaian.

\section{DAFTAR PUSTAKA}

Aguilera, A. (2005). Growth in commuting distances in French polycentric metropolitan areas: Paris, Lyon and Marseille. Urban Studies, 42(9), 15371547.

Brenner, N. (1999). Globalisation as Reterritorialisation: The Re-scaling of Urban Governance in the European Union. Urban Studies, 36 (3), 431-451.

Brenner, N. (2003). Metropolitan institutional reform and the rescaling of state space in contemporary Western Europe. European Urban and Regional Studies, 10(4), 297-324.

Borck, R., Pflüger, M., \& Wrede, M.(2010). A simple theory of industry location and residence choice. J Econ Geogr, 10 (6), 913-940.

Buliung, R.N. \& Kanaroglou, P.S. (2002) Commute minimization in the Greater Toronto Area: Applying a modified excess commute. Journal of Transport Geography, 10. 177-186

Camagni, R., Gibelli, M. C., \& Rigamonti, P. (2002). Urban mobility and urban form: the social and environmental costs of different patterns of urban expansion. Ecological Economics, 40(2), 199-216.

Ding, C., Mishra, S., Lu, G., Yang, J., \& Liu, C. (2017). Influences of built environment characteristics and individual factors on commuting distance: A multilevel mixture hazard modeling approach. Transportation Research 
Part D: Transport and Environment, 51, 314-325.

Engelfriet, L., \& Koomen, E. (2017). The impact of urban form on commuting in large Chinese cities. Transportation, 1-27.

Firman, T. (2004). Major issues in Indonesia's urban land development. Land Use Policy, 21(4), 347-355.

Firman, T. (2009). Decentralization Reform and Local-Government Proliferation in Indonesia: Towards a Fragmentation Of Regional Development. Review of Urban \& Regional Development Studies, 21 (23). 143-157.

Firman, T. (2014). Inter-local-government partnership for urban management in decentralizing Indonesia: from below or above? Kartamantul (Greater Yogyakarta) and Jabodetabek (Greater Jakarta) compared, Space and Polity, 18(3). 215-232.

Firman, T., \& Fahmi, F. Z. (2017). The Privatization of Metropolitan Jakarta's (Jabodetabek) Urban Fringes: The Early Stages of "Post-Suburbanization" in Indonesia. Journal of the American Planning Association, 83(1), 68-79.

Giuliano, G., \& Small, K. A. (1993). Is the journey to work explained by urban structure? Urban Studies, 30(9), 1485-1500.

HABITAT III: New Urban Agenda. (2016). The United Nations Conference on Housing and Sustainable Urban Development.

Harmadi, S.H.B., Yudhistira, M.H., \& Koesrindartono, D.P. (2015). How does congestion matter for jakarta's citizens?. Journal of Indonesian Economy and Business, 30(3). 220-239

Heinelt, H., \& Kübler, D. (2005). Metropolitan Governance : Capacity, democracy and the dynamics of place, London: Routledge

Henderson, J. V., Kuncoro, A., \& Nasution, D. (1996). The Dynamics of Jabotabek Development. Bulletin of Indonesian Economic Studies, 32(1), 71-95.

Hill, R. C. (1974) "Separate and unequal: governmental inequality in the metropolis." Amer. Pol. Sci. Rev, 68(4). 1557-1568

Horner, M. W. (2004). Spatial Dimensions of Urban Commuting: A Review of Major Issues and Their Implications for Future Geographic Research*. The Professional Geographer, 56(2), 160-173.

Hudalah, D. (2017). Governing industrial estates on Jakarta's periurban area: From shadow government to network governance: Governing industrial estates. Singapore Journal of Tropical Geography, 38(1), 58-74.

Hudalah, D., Viantari, D., Firman, T., \& Woltjer, J. (2013). Industrial Land Development and Manufacturing Deconcentration in Greater Jakarta. Urban Geography, 34(7), 950-971.

Innes, J.E. \& Booher, D.E. (2010). Beyond Collaboration Democratic Governance for a Resilient Society. in: Planning with Complexity, An Introduction to collaborative rationalityor public policy, Routledge: Oxon.

Lefèvre, C. (1998), Metropolitan government and governance in western countries: a critical review. International Journal of Urban and Regional Research, 22. 9-25.

Lowery, D. (1998). Consumer Sovereignty and Quasimarket Failure. Journal of Public Administration Research and Theory 8(2). 137-172. 
Mardianta, A.V., (2017). Peran pemerintah daerah dalam rescaling pengelolaan kawasan metropolitan studi kasus: Penyelenggaraan BRT di kawasan Mebidang, (PhD Thesis), Instititute of Technology Bandung

Mardianta, A.V., Kombaitan, B., Purboyo, H., \& Hudalah, D. (2016). Pengelolaan Kawasan Metropolitan di Indonesia dalam Perspektif Peraturan Perundangan. in: Prosiding Temu Ilmiah IPLBI 2016, Malang, . c051-c056.

Okitasari, M., \& Kidokoro, T. (2012). Policy and Institutional Reform of Indonesian Planning System: Nexus to Metropolitan and Local Planning Effectiveness. Paper presented in AESOP $26^{\text {th }}$ Annual Congress. Ankara. 11-15 Jul

Ostrom, E., (1972). Metropolitan Reform: Propositions Derived from Two Traditions, Social Science Quarterly 53(4). 474-493.

Pereshtu, A. (2002). Jakarta's "exurbia" kampongs. Research Reports. Urban Perspective, 1, 49-58

Rusk, D. (1995). Cities Without Suburbs (2 $2^{\text {nd }}$ Ed.). Washington: Woodrow Wilson Center.

Salet, W., Thornley, A. \& Kreukels, A. (2003). Metropolitan Governance and Spatial Planning : Comprehensive Case Studies of European City-Regions, Spons Press.

Schwanen, T. (2002). Urban Form And Commuting Behaviour: A CrossEuropean Perspective. Tijdschrift Voor Economische En Sociale Geografie, 93(3), 336-343.

Sellers, J., \& Hoffmann-Martinot, V. (2008). Metropolitan Governance. in: United Cities and Local Governments, World Report on Decentralization and Local Democracy. 255-279.

Schwanen, T., Dieleman, F. M., \& Dijst, M. (2004). The impact of metropolitan structure on commute behavior in the Netherlands: a multilevel approach. Growth and Change, 35(3), 304-333.

Tarko, V. (2015). Polycentric Governance: A Theoretical and Empirical Exploration. (Phd Thesis). George Mason University

United Nations, Department of Economic and Social Affairs, \& Population Division. (2014). World urbanization prospects: the 2014 revision: highlights.

van der Heiden,N., Koch, P., \& Kübler, D. (2013). Rescaling metropolitan governance: examining discourses and conflicts in two Swiss metropolitan areas, Urban Research \& Practice, 6(1), 40-53,

Winarso, H., Hudalah, D., \& Firman, T. (2015). Peri-urban transformation in the Jakarta metropolitan area. Habitat International, 49, 221-229

Wheeler, S.M. (2002). The New Regionalism: Key Characteristics of an Emerging Movement. Journal of the American Planning Association, 68(3). 267-278.

World Bank Group. (2016). Indonesia's Urban Story; The role of cities in sustainable economic development (p. 28).

Zhao, P., Lü, B., \& Roo, G. de. (2011). Impact of the jobs-housing balance on urban commuting in Beijing in the transformation era. Journal of Transport Geography, 19(1), 59-69. 